\title{
The basic functions and governance of urban rivers
}

\author{
Zhonghua $\mathrm{Hu}^{1,2, \mathrm{a}}$ \\ ${ }^{1}$ School of History and Culture, Sichuan University, Chengdu, Sichuan Province, China. \\ ${ }^{2}$ Chengdu Medical College, Chengdu, Sichuan Province, China. \\ ahzh754574517@163.com
}

\begin{abstract}
Keywords: Urban River, Function Supervision.
\end{abstract}
\begin{abstract}
River plays an important role in the formation, origin and development of the city. Regarding the world famous city, there is always a famous river accompanying it and it is the common choice of human being to build a city near the river. Before the modern times, the city and the city river were in harmony. After the industrial revolution, the process of urbanization was accelerated, the rapid expansion of urban areas, urban land area was a geometric growth, and the city is constantly changing the natural landscape. At the same time, human beings intensified the usages and development of rivers, causing the obvious change of rivers' function in the city and the ability of fighting flood is declining. Once the torrential rain came constantly, in many cities a large area of water will come into being. River pollution and the ecological environment are also increasingly degraded, affecting people's daily life. With the progress of the times, people began to reconsider the relationship between the city and the river and pay more and more attention to the issue of the city. At this stage, the basic idea of dealing with urban river is to ensure the basic functions of flood control, water supply safety and other basic functions, after which people can be concerned about the river ecological restoration and waterfront landscape construction and development.
\end{abstract}

\section{Introduction}

River is a cradle of the birth of the city, which plays an important role in the formation of the city and the origin and development of the city. About five thousand years ago, urban civilization appeared in the Mesopotamia plain between Iraq's Euphrates and the Grass River, marking the appearance of a civilized society. Chinese civilization originated from the Yellow River and the Yangtze River where a large number of cities appeared, which has become an important source of the world's urban civilization. Up to now the alluvial plain and Delta region of the world are still the developed areas of human society economy and culture, and it is also the most densely distributed area of the city.

About the world famous cities, there Is always a famous river to accompany. It is a common choice of human being to build a waterfront city. In Europe, the Rhine and the Danube gave birth to the developed urban agglomeration on both sides. In our country, the lower reaches of the Yangtze River, the Yellow River and the Pearl River are the most concentrated areas in the city. In the city, there are large and small rivers or lakes distributed in the meantime, and the city water system functioned as the city's development axis, which determines the city's overall shape. Wharfs, handicraft industry, commerce and other construction concentrated areas all emerged along the main river system like a strip of space layout. It is the rivers in the city or outside of the city that contribute to the cities. During the evolution of the city, the city and the river have been integrated early.

Compared with the natural river, the relationship between human beings and the city river are much closer, "referring to the city river originating from the city or flowing through the city or river sections of the city region, including some artificial excavation canals with a long history, but after years of evolution which have the characteristics of the natural rivers. " [1] As can be seen from the definition, urban rivers and the city has been integrated into an organic part of the city. Human activities have a profound impact on the hydrological characteristics of urban rivers and ecological environment. At the same time, the city's social and economic system and the daily life of residents cannot be separated from the various services provided by the city's rivers. 


\section{First, the basic functions of urban rivers}

City River plays an important role for the city residents in living and production, for the city location and city terrain are different, and the difference between the sizes of a river, the function of the river will be different, but the basic function is consistent and plays an important role in city life and production. Its main functions are as follows:

1, the function of getting rid of flood waterlogging. Every river has its specific river basin; this basin must smoothly discharge its flood. Once the floods are poorly drained, it will cause significant loss. If the population and resources are intensive, the loss will be greater. In history the city is always developed according to the use of various water sources and the precautions against flood. In recent years, once many large cities encountered heavy rains, it must have poor drainage and flood, and even drowning tragedy. At the same time, urban river is generally the discharge channel of urban waste water. 2, the water resources security function, in the early development of the city, city river was once an important source of drinking water of the city, now because of water pollution, drinking water function does not exist any more, but the city river to meet the industrial production and the ecological water still plays an important role. 3 , the function of city waterscapes, the city cannot do without water. Rivers often constitute the city's beautiful landscape axises, forming a beautiful landscap of the city, and even become the city's business cards. For example, the Haihe River in Beijing, the royal gardens of West Lake, the beautiful scenery of Tianjin, which are representatives of the city sights 4 , maintain urban ecosystem function, due to the limited land resources, intensive population and buildings, ecological system is monotonous and fragile. River city can play a very good regulation; meanwhile river city can provide a good habitat for aquatic animals. Woods and wetland on both sides of the river also can supply a comfortable living space to the amphibious animals and birds. 5, waterway navigation function, most of the rivers in the city in ancient times have an important waterway navigation function, which are important traffic lines of the city and it has counted great in the city's trade and foreign exchange. However, at present River flow is generally decreased, mostly not navigable, while city road traffic developed quickly, so it is not necessary

for the city to use river water as transportation, but to maintain the smooth flow of rivers and to develop water tourism in many cities are still in demand.

\section{Two, the problems faced by urban rivers}

Since the birth of human civilization, human beings adjusted surface runoff through the construction of water conservancy project, in order to facilitate the use of various water resources and flood defense. Since the industrial age, the consumption of water has sharply increased, and the scales of all kinds of water conservancy projects have expanded larger and larger and the water from the river to its tributaries is used to build a dam to store water and irrigation. City is a symbol of human civilization, and the transformation towards city river is more intensive. In the process of reconstruction of city rivers, we gain and lose. In the process of urban development, because of the change of the whole system and the process of natural evolution towards the river, its effect is serious. Many wanton transforms against the nature caused the destruction of the city's rivers . Many cities use city water system as the city's sewage channel or landfill, as a result, the water was polluted or abandoned; digging sands and getting stones damaged river landscape, endangered the safety of river and formed a huge hidden trouble to the city; the development of the city water system space is occupied by road or construction ; the city river is cut off at random, landfilled or changed from open channels into culvert channels which severely caused the destruction of the ecosystem; to emphasize the temporary flood discharge capacity , the city river was cutoff, and human beings use the cement to anti-flood bank, or build a dam to storage, causing the decrease of its self-cooling ability and even this ability disappeared. Even in order to beautify the river, the river is changed in the form of artificial ways such as "beautification" "geometry" and "artificial". Along the riverside, it is covered even completely by a large number of "landscape square", rather than natural green land. It is difficult to find a natural rive in the city. 
Due to the change of the river course without science, and because the river channel is occupied seriously, the industrial and living waste water is discharged in quantity; many urban rivers appear different degree of layer of problems: 1, drainage capacity decreased, the river was artificially changed; some city rivers have become landfill sites, which destroyed the drainage system of the natural form . Once it encountered heavy rains, many flooding cases occurred in many cities. 2, artificial skills count great in many cities . Taking flood safety for consideration, people converted a river to a straightening one, riverbed with concrete reinforcement, and city river becomes an artificial river, where many natural habitats of species disappeared. 3 , river pollution is serious, and a lot of waste water is directly discharged into the river, so the water in the river is generally black and odorous and ecological functions decline. Some perennial rivers are stink, seriously affecting people's lives. 4, the occupation of the river, people get more land generally and make a short-term development by occupying the river, at the same time causing the destruction of the ecological system of city rivers, and flood discharge capacity is reduced.

\section{Three, the governance of urban rivers}

Before modern times, owing to the limited size of the city, city land is relatively abundant. People do not need to occupy river beds, so the river basically maintained the original appearance. Without the pollution source of modern industry, the water quality of the city river is good, and the pollution is not serious. Human transformation of urban rivers is mainly for flood control, so the scale of the transformation is not large, and the level is not deep, because people have a reverence idea for the river, and many cities have been called the city's "Mother River" ". On the whole, the relationship between the city and the city is harmonious. After the industrial revolution, cities have been built in a large scale and the use of urban land becomes increasingly intensive. At the same time, more and more people believe their ability to transform nature. People began to notice the river, and the river wanton transformation has begun, which makes the river narrower than before; more buildings are built on the occupied land; waste water is set off arbitrarily, making it into the garbage dump. many city rivers are polluted, stinking, seriously affecting people's life. In China, the situation is more prominent. In July 2012, a heavy rain hit Beijing, resulting in more than 70 deaths[2] , Insufficient drainage function of the city completely was unmasked. in Many world cities, the drainage system has to face severe challenge once it encountered heavy rains. With the development of society and economy, more and more people pay attention to the problems of urban rivers. This series of events make people realize the urgency of urban river management.

The traditional city rivers mainly are used to fight against flood, and most of project management methods are canalization and hardening, such as high embankments, rock slope protection, straightening on both sides of the river. Hardening, drainage, flood control, water transport are focused only on the utilitarian value, while people always ignore other function s of the river, and the destruction of the ecological environment of natural rivers has not been considered. Adverse effects are mainly as follows. 1 , the speed of water flow is accelerated, and the river bed is exacerbated by the erosion of water flow. Once it is the storm season, the river is easy to burst its bank. 2, river landscape was destroyed; the water is reduced, reducing the public's leisure places. 3 , because of the destruction of the natural eco-system of the river, and reduction of the biological diversity, it is not conducive to maintaining the ecological balance. 4, river pollution is serious, and serious deterioration of water quality affected the lives of the people. 5, the river city disappeared, reducing the city's drainage channels, easy to form a flood.

River is related to all aspects of human life; it is a dynamic, complex ecosystem, which can provide a lot of ecological and economic services for human beings. "The process of urbanization has intensified human" s development and utilization of nature, and increased the destruction to the natural environment, which has become a prominent contradiction in the development of the city. Rapid population growth leads to water resources, land resources becoming increasingly tense, and the river ecosystem is deteriorating, " [3] Rivers and wetlands are the most threatened ecosystems in the world. [4] Urban rivers have a greater impact on the city, and they need the protection of human beings. 
In the process of continuous management of the river, people summed up the lessons learned, and gradually explored some of the city's good ways of river management. At present, the functional requirements of City River have been changed, focusing from the basic functions of flood control and drainage, water supply safety, to the function of flood control, drainage, water supply, environment, landscape, ecology and culture. At home and abroad, under the premise of ensuring the safety of flood control, water supply, the thoughts of river management are gradually developed towards ecological restoration and construction of waterfront landscape.

1 , the ecological restoration is an important part of river management. Under the condition of protection, restoration and reconstruction of "biological survival necessary habitat and under the premise of ensuring the safety of the river flood control, people have to control the emission of sewage, and remove hard revetment, establish buffer zone, plant aquatic plants, and protect aquatic animals, so as to improve the filtration ability and riparian River self-purification ability . Under the premise of flood prevention, human beings try their best to restore the natural landscape of the river, so that the city's rivers glow their vitality.

2 , waterfront landscape environment construction is the focus of city construction. City waterfront space is often the city public hydrophilic places, and it is also the focus of city construction and development. A lot of high-end real estates and parks are built in the river. Walking in the leisure time has become a dream of city people. Since 1960s, many countries pay special attention to the comprehensive development of city waterfront space, making it beautiful scenery with fresh air, entertainment facilities for residents. Some of the city's waterfront landscapes also promote the characteristics of tourism, improving the image of the city.

The most successful countries of river management and repair in the world are the United States, Japan and European countries as the representatives. The construction of Baltimore and Inner Harbor waterfront in Yokohama in Japan are the representatives of the construction of waterfront development, fundamentally changing the waterfront space image, and regaining its vitality. [5] At the end of 1950s, the beautiful Thames River became a dead River and dirty water has become the culprit of the spread of the disease. In the 1960s, the British government began a complete management of Thames River. First of all, by making a law, the government made a strict regulation on the discharge of industrial waste water into the Thames River. They take so many measures such as reconstruction and extension of the London sewer, the construction of hundreds of sewage treatment plants, forming a complete urban sewage treatment system. After more than 20 years of governance, it has become one of the world's cleanest city waterways, becoming a model of urban river governance.

In our country rivers a successful case is Funan River treatment project in Chengdu, which is the Eco Park with the theme of water treatment. The polluted water extracted from the Funan River becomes a "living water standard" by Wetland Park and the natural ecological purification. After extraction, the purified water returns the river. On both sides of the river they planted trees and green grass, with more public facilities, so that the people along the river have a good place for public leisure and entertainment. In the process of building the park, pay attention to the history and the heritage of culture and leisure in Chengdu, which is also a cultural project construction. With the increase of the surrounding land value, estate developments are in full swing, and it effectively promotes the development of the economy. The success of Funan River treatment project includes the sustainable development of the city, city construction and environment, housing and other aspects of the connotation, which is a successful example of China's city of river management.

\section{References}

[1] Song Qing hui, Yang Zhi feng, Thinking of integrated management of urban rivers in China, Advances in water science, Vol 13 No 3 May 2002, 377-382

[2] People. com, on July 26th, 2012, the victim toll has raised to 79 in the heavy rain

[3] NIJLAND H J, CALS M J R. River restoration in Europe practical approaches, conference on river restoration[R]. LA Utrecht, The Netherlands:Europe Center for River Restoration, 2001 
[4] BRINSON M M, MALVAREZ A I. Temperate freshwater wetlands:types, status and threats [J]. Environmental Conservation, 2002, 29(2):115-133

[5] MISEKI T, TAKAZAWA H. Project for creation of river rich in nature-towards a richer environment in towns and on watersides[J]. Journal of Hydroscience and Hydraulic Engineering: Special Issues, 1993(4):86-87. 